Egyptian Journal of Aquatic Biology \& Fisheries

Zoology Department, Faculty of Science,

Ain Shams University, Cairo, Egypt.

ISSN $1110-6131$

Vol. 23(1): 403 - 411 (2019)

www.ejabf.journals.ekb.eg

\title{
Reproductive Biology of the Common Sole, Solea solea in Southern East Mediterranean, Bardawil Lagoon, Egypt
}

\author{
Attia A. O. El- Aiatt, Kariman A. Sh. Shalloof and Alaa M. El- Far
}

Fisheries Division, National Institute of Oceanography and Fisheries, Egypt

\begin{abstract}
ARTICLE INFO
Article History:

Keywords:

Solea solea

Bardawil Lagoon

Mediterranean

Reproduction

Management

Fisheries
\end{abstract}

Received: Jan. 25, 2019

Accepted: March 19, 2019

Online: March 30, 2019

\begin{abstract}
Annual production of soles in Bardawil Lagoon was gradually decreased from 343 MT in 2008 to be 161 MT in 2016. This work aims to investigate reproductive biology of the common sole, Solea solea, to provide biological base for management of its fisheries in Bardawil Lagoon, North Sinai, Egypt. Monthly samples of $S$. solea were collected from the commercial catch in different landing sites of the lagoon during 2016-2017. The length-weight relation was found as $\mathrm{W}=0.0055 \mathrm{~L}^{3.171}, \mathrm{~W}=$ $0.0047 \mathrm{~L}^{2.334}$ and $\mathrm{W}=0.0048 \mathrm{~L}^{3.2215}$ for males, females and combined sexes respectivly. Generally, low values of condition factors were recorded in June and July, and the highest value was recorded in December. GonadoSomatic Index (GSI) of females showed that $S$. solea spawn during November, December and January since GSI peaked in these months (6.77, 8.72 and $8.48 \%$ respectively). The lowest value of GSI of females was recorded in August (1.09\%). Overall sex ratio (males : females) was 1: 1.99 during the period of study. Lengths at first sexual maturity $\left(\mathrm{L}_{\mathrm{m}}\right)$ were determined as 19.8 and $20.1 \mathrm{~cm}$ for males and females respectively. The absolute fecundity $(\mathrm{F})$ was increasing with the fish length and described by a power equation: $F=7.0918 \mathrm{~L}^{\mathbf{3 . 6 3 7 4}}$. The relative fecundity gradually increased from 8092.5 to 36680.6 eggs per cm (average 20766.6 eggs/ $\mathrm{cm})$. To protect and maintain the stock of common sole in Bardawil Lagoon, it is recommended to ban using fishing nets of illegal mesh sizes and other destructive fishing methods which catch small fish sizes, length at first capture should be larger than length at first sexual maturity $(>20.1$ $\mathrm{cm}$ ) and ban fishing nets targeting soles during its spawning season (from November to January).
\end{abstract}

\section{INTRODUCTION}

Bardawil Lagoon fishes is considered the most Egyptian marine fish required for export because the lagoon is the cleanest marine water body in Egypt, as well as in the entire Mediterranean region (Noor-ElDeen et al., 2016). The lagoon catch composed mainly of seabass, seabream, soles, mullets, crabs and shrimps. According to official statistics, catch of soles is gradually decreased from 343 MT during 2008 to be 161 MT during 2016. Average catch of soles represented by $4.4 \%$ of the total lagoon production $(4325 \mathrm{MT})$ for the last 10 years. In 2016, the production values of soles were estimated to be about 10 million Egyptian pounds (GAFRD, 2018).

Common sole, Solea solea, and Egyptian sole, S. aegyptiaca, (Order: Pleuronectiformes; Family: Soleidae) are the most important soles species that occurs in the Egyptian waters. They tend to occupy shallow, sandy and sandy/muddy habitats as well as 
the shallow lagoons. Despite its worldwide importance, little work has been dedicated on its reproductive biology. Members of the genus Solea are recorded among the most important and valuable commercial flatfishes in Egypt and greatly appreciated by consumers of sea products (Gabr et al., 2003).

Understanding the reproductive biology of a species is a central aspect of providing sound scientific advice for fisheries management. Reproductive biology plays an important role in determining productivity and therefore a population's resiliency to exploitation by fisheries or to perturbation caused by other human activities (Morgan, 2008). Aspects of the flatfish reproduction were described by many studies in Egypt (Zaki and Hamza, 1986 and Mehanna, 2007) and from others locations in the world (Rajaguru, 1992; Vallisneri et al., 2001; Türkmen, 2003; Narimatsu et al., 2005 and García-López et al., 2006). In Egypt, the information about the reproductive biology of this species was very scarce (Salman, 2014). This study aims to understand the reproductive biology of the common sole in Bardawil Lagoon as an effective tool for its fisheries management.

\section{MATERIALS AND METHODS}

\section{Area of study}

Bardawil Lagoon is a shallow, hypersaline lagoon, located in the north of Sinai southern east the Mediterranean Sea. Its coordinate is about $31^{\circ} 10^{\circ} \mathrm{N} 33^{\circ} 12 \mathrm{E}$. It extends for about $80 \mathrm{~km}$ with a maximum width $20 \mathrm{~km}$ and a maximum depth of $3 \mathrm{~m}$ (Fig., 1).

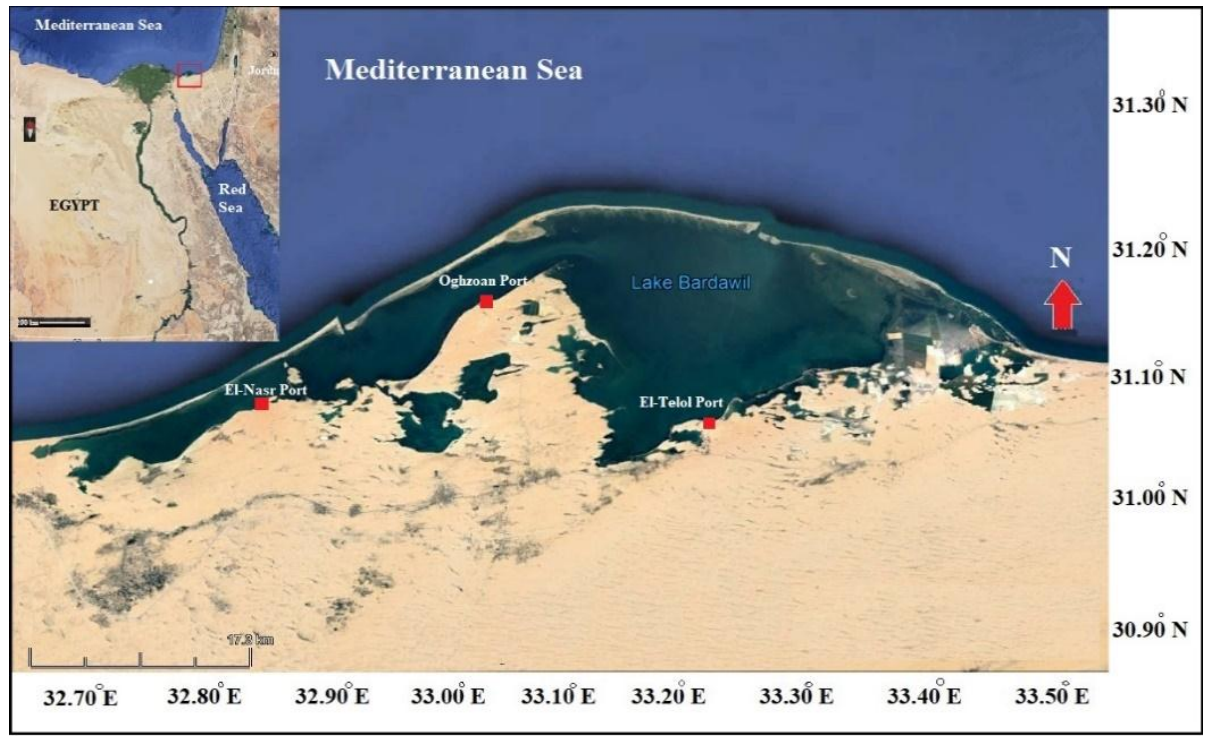

Fig. (1): A map of Egypt showing the location of Bardawil Lagoon and the landing sites.

\section{Samples collection}

Monthly random samples of S. solea (Fig., 2) were collected from the commercial catch in different landing sites of the Bardawil Lagoon during the fishing season from May, 2016 to January, 2017. In the laboratory, total fish length and total weight for 1643 specimens were measured to the nearest $0.1 \mathrm{~cm}$ and $0.1 \mathrm{~g}$, respectively. Fish specimens were dissected to determine its sex and maturity stages. The gonads were weighed to the nearest $0.01 \mathrm{~g}$ and the ovaries were preserved in $10 \%$ formalin for subsequent examinations. 


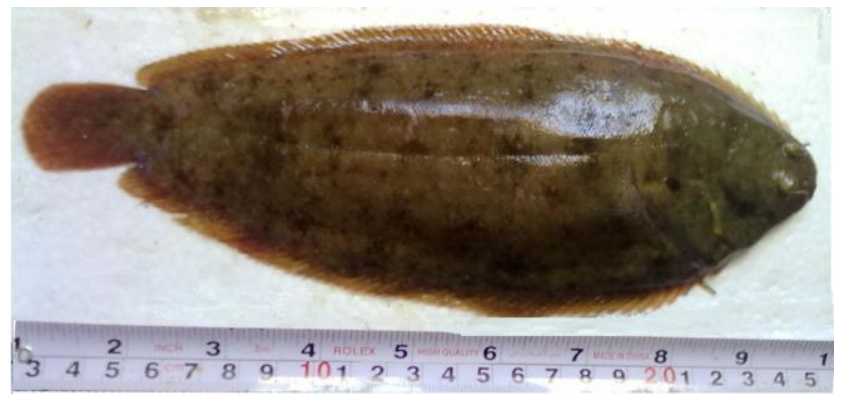

Fig. 2: Common sole, Solea solea, from Bardawil Lagoon, Egypt.

\section{Data analysis}

The relationship between length and weight was described by the potential equation: $\boldsymbol{W}=\boldsymbol{a} \boldsymbol{L}^{\boldsymbol{b}}$ (Ricker, 1975), where: $\boldsymbol{W}$ is the total weight $(\mathrm{g})$, and $\boldsymbol{L}$ is the total length $(\mathrm{cm}), \boldsymbol{a}$ and $\boldsymbol{b}$ are constants. The condition factor $(K)$ was calculated monthly by formula $K=\left(W^{*} 100\right) / L^{3}$ (Hile, 1936), where: $\boldsymbol{W}$ is the body weight (g) and $\boldsymbol{L}$ is total length (cm).

Maturity stages were adopted based on the morphological changes that take place in the gonads during maturity development (Nickolsky, 1963). The gonado-somatic indices (GSI) were calculated by equation of Albertine-Berhaut (1973) as follows:

$\boldsymbol{G S I}=($ Gonad Weight $/$ Body Weight $) * 100$.

For estimation of the length at first maturity, the total body length was plotted against the frequency percentage of mature individuals during the spawning season, and then the length at $50 \%$ considered as the length at first maturity (Sendecor, 1956).

The absolute fecundity $\left(\boldsymbol{F}_{a b s .}\right)$ is defined as the number of mature eggs in the ovaries during the spawning season. Numbers of 77 mature ovaries were used to determine fish fecundity. Mature ovaries were taken, washed, dried and weighted. Then the ovarian tissue was removed and the net eggs weight was obtained. Eggs were well mixed, and three subsamples were weighted and counted under the microscope. Total fecundity was calculated according to Yeldan and Avsar (2000) as:

$\boldsymbol{F}_{\boldsymbol{a b s .}}=[($ Gonad weight* Egg number in the subsample $) /$ Weight of subsample $]$.

The relative fecundity $\left(\boldsymbol{F}_{\text {rel. }}\right)$ was calculated as:

$\boldsymbol{F}_{\boldsymbol{r} \boldsymbol{e l} .}=\boldsymbol{F}_{\boldsymbol{a b s} .} /$ (Total length or Body weight).

\section{RESULTS}

Length-weight relationships: A total of 1643 specimens of S. solea were obtained from the commercial catch of Bardawil Lagoon from May, 2016 to January, 2017. The fish total length ranged from 11.5 to $29.8 \mathrm{~cm}$ and the observed total weight ranged from 13 to $225.3 \mathrm{~g}$. The length - weight relationship was described by the power equation as:

$\mathrm{W}=0.0055 \mathrm{~L}^{3.171}\left(\mathrm{R}^{2}=0.9398\right)$ for males (Fig., 3),

$\mathrm{W}=0.0047 \mathrm{~L}^{3.2334}\left(\mathrm{R}^{2}=0.9558\right)$ for females (Fig., 4) and

$\mathrm{W}=0.0048 \mathrm{~L}^{3.2215}\left(\mathrm{R}^{2}=0.951\right)$ for combined sexes (Fig., 5).

Condition Factor: The mean condition factors for males, females and combined sexes were nearly similar to each other. Lower condition factor values $(\mathrm{K})$ were recorded in July and October while the highest values were in December (Fig. 6). Also, the study revealed a decline in $\mathrm{K}$ during August in males and a slight increase in females.

Sex ratio: In whole samples, the sex ratio of $S$. solea was 1: 1.99, where males represented by 549 individuals and females represented by 1094 individuals). Table (3) shows that the two sexes did not distributed in the same proportion during different months. Females predominated during all months, since it constitutes more than $60 \%$ of the collected sample during the period of study. 


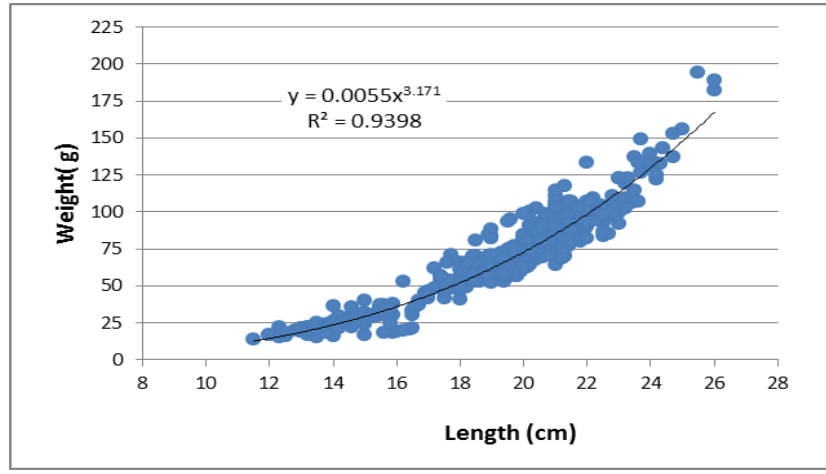

Fig. 3: Length weight relationship of males for S. solea from Bardawil Lagoon during 2016-2017.

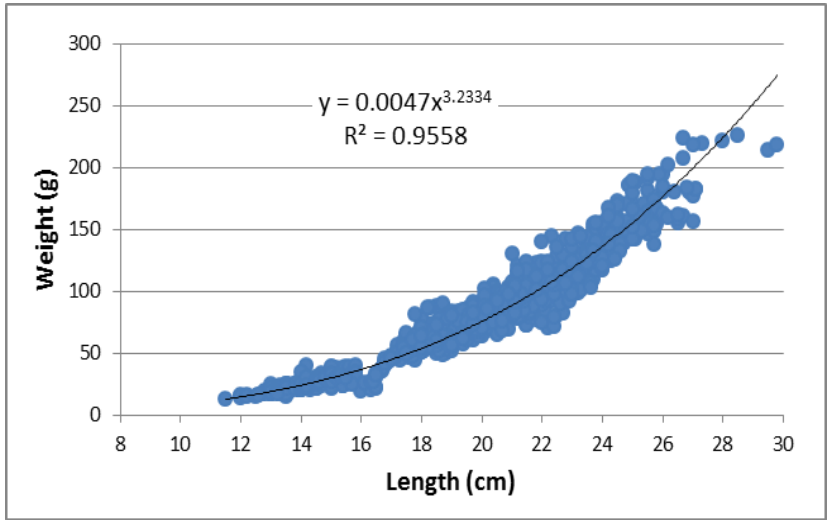

Fig. 4: Length weight relationship of females for S. solea from Bardawil Lagoon during 2016-2017.

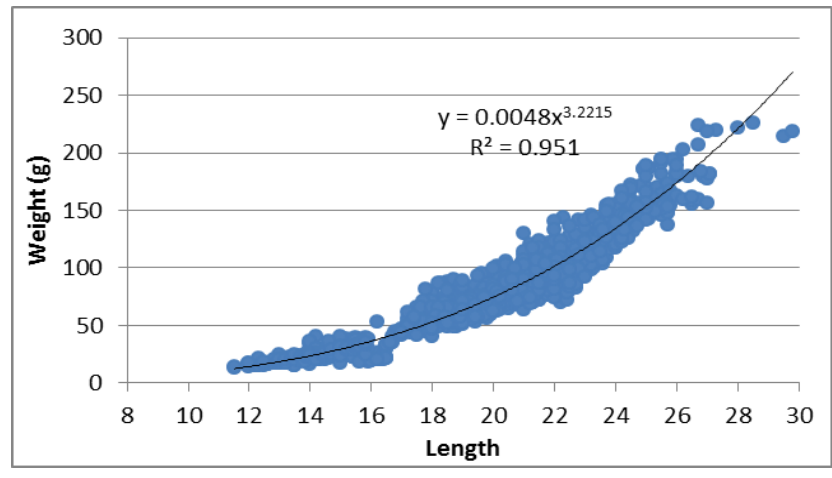

Fig. 5: Length-Weight. relationship of combined sexes for S. solea from Bardawil Lagoon during 2016-2017.

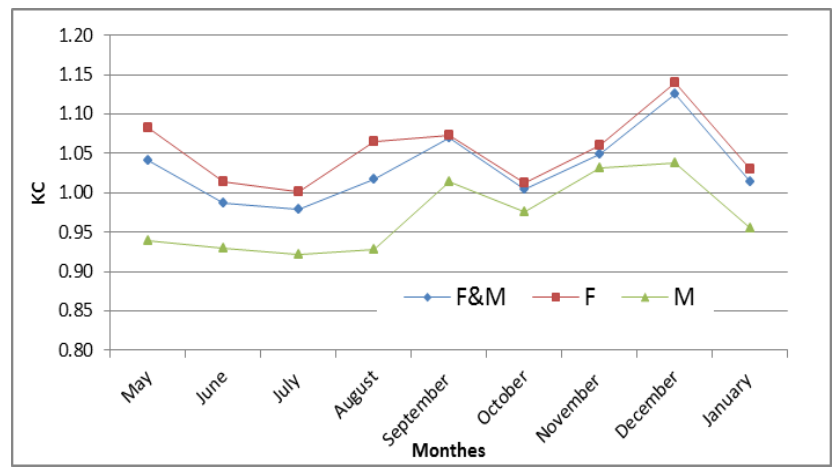

Fig. 6: Monthly variation in condition factor (K) of combined sexes (F\&M), females (F) and males (M) of $S$. solea during 2016-2017. 
Table 1: Monthly variations in sex ratio of S. solea in Bardawil Lagoon during 2016-2017.

\begin{tabular}{lcccccc}
\hline \multirow{2}{*}{ Month } & No. of fish & \multicolumn{2}{c}{ Females } & \multicolumn{2}{c}{ Males } & Sex ratio \\
\cline { 3 - 7 } & & No. & $\mathbf{\%}$ & No. & \% & M/F \\
\hline May 2016 & 166 & 107 & 64.5 & 59 & 35.5 & $1-1.8$ \\
Jun. 2016 & 163 & 113 & 69.3 & 50 & 30.7 & $1-2.3$ \\
Jul. 2016 & 147 & 102 & 69.4 & 45 & 30.6 & $1-2.3$ \\
Aug. 2016 & 167 & 113 & 67.7 & 54 & 32.3 & $1-2.1$ \\
Sep.2016 & 160 & 107 & 66.9 & 53 & 33.1 & $1-2.0$ \\
Oct. 2016 & 229 & 157 & 68.6 & 72 & 31.4 & $1-2.2$ \\
Nov. 2016 & 202 & 119 & 58.9 & 83 & 41.1 & $1-1.4$ \\
Dec. 2016 & 199 & 146 & 73.4 & 53 & 26.6 & $1-2.8$ \\
Jan. 2017 & 210 & 130 & 61.9 & 80 & 38.1 & $1-1.6$ \\
Total & 1643 & 1094 & 66.6 & 549 & 33.4 & $1-1.99$ \\
\hline
\end{tabular}

Regarding to fish length, it was noticed that females' individuals were outnumbered males individuals for all length groups. In length group $(20.0-20.9 \mathrm{~cm})$ the sex ratio is closer to $1: 1$ (Fig. 7).

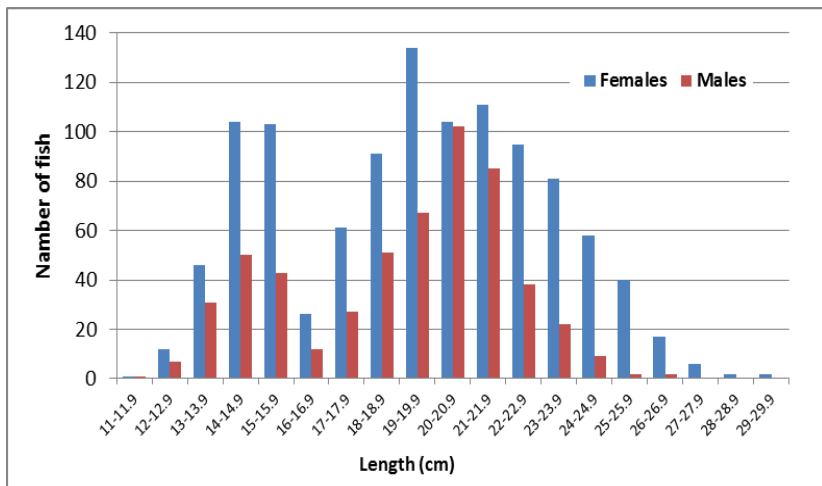

Fig. 7: Sex ratio by length groups of S. solea in Bardawil Lagoon during 2016- 2017.

Gonado-somatic index (GSI): The monthly changes in males and females GSI of $S$. solea were represented in figure (8). GSI values of males were lower than females. The lowest value of GSI of males (0.29) was recorded in August, and it started to increase slightly from September to November. On the other hand, highest value of GSI (1.58) was recorded in December. Values of GSI of females showed a similar pattern that of males. It attained the lowest value (1.09) in August and increase slightly to highest value (8.72) in December. This means that $S$. solea in Bardawil Lagoon is a winter spawner.
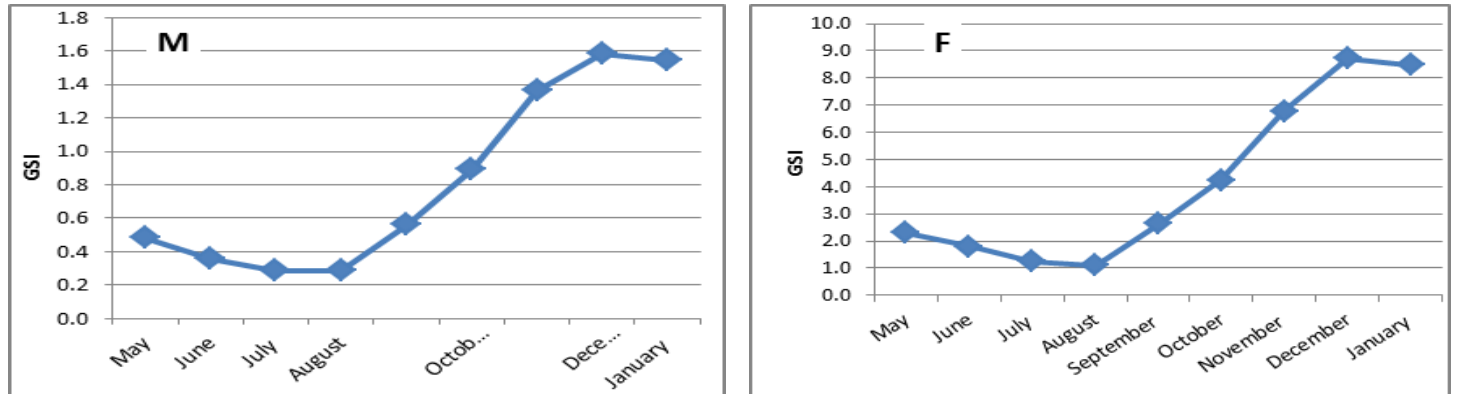

Fig. 8: Changes in Gonado Somatic Index (GSI) of males (M) and females (F) of S. solea in Bardawil Lagoon during 2016- 2017.

Length at first sexual maturity: The immature and mature fish for each length group was analyzed to determine the length at first mature $\left(\mathrm{L}_{\mathrm{m}}\right)$. All males and females with a total 
length higher than $20 \mathrm{~cm}$ are mature. The length at first maturity $\left(\mathrm{L}_{50}\right)$ was determined as 19.8 and $20.1 \mathrm{~cm}$ for males and females respectively (Fig. 9).

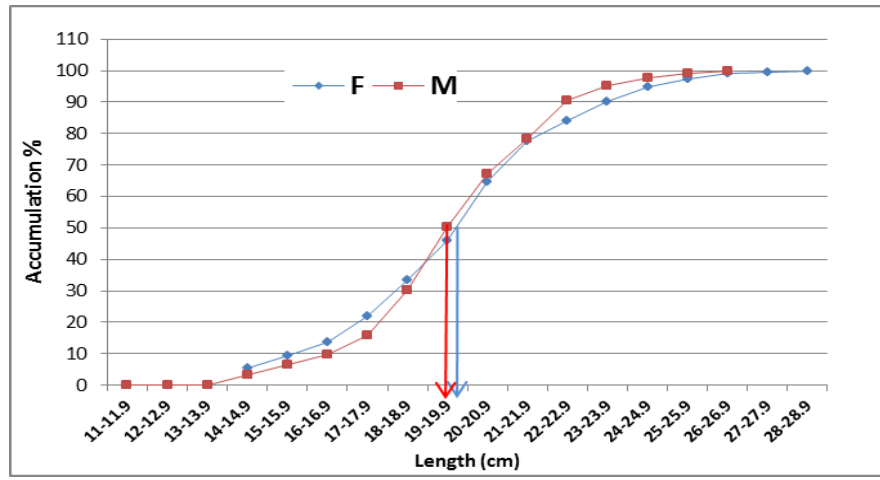

Fig. 9: Length at first sexual maturity $\left(\mathrm{L}_{\mathrm{m}}\right)$ of males and females $S$. solea during 2016-2017.

Fecundity: The relation between fecundity (absolute and relative) with body size (total length) and body weight of $S$. solea were calculated. The results found that the number of eggs gradually increased by increasing fish length or weight, since fish of $14 \mathrm{~cm}(23.8 \mathrm{~g})$ bears about 121400 eggs, reaching maximum of about 1028000 eggs for a fish length 28.5 $\mathrm{cm},(225.3 \mathrm{~g}$.). The absolute fecundity- total length relationship (Fig. 10) was represented by power equation as following: $F=7.0918 \mathrm{~L}^{\mathbf{3 . 6 3 7 4}}\left(\mathrm{R}^{2}=0.9378\right)$.

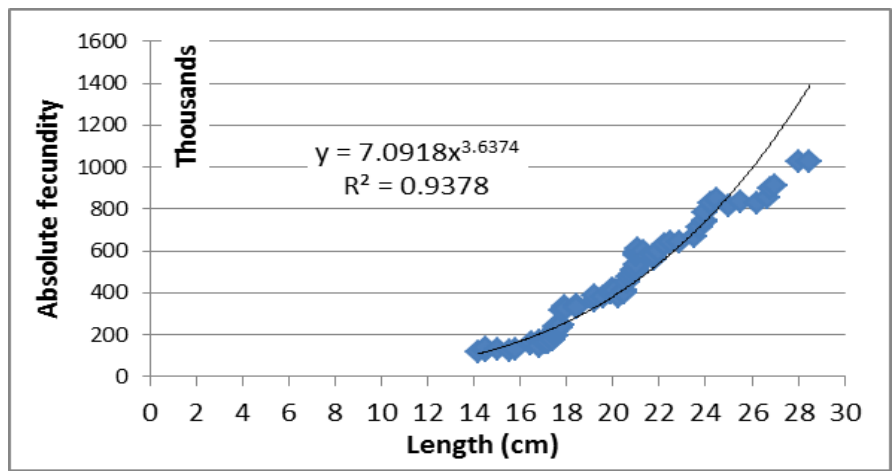

Fig. 10: Relationship between total length and absolute fecundity of S. Solea during 2016-2017.

The relative fecundity gradually increased from 8092.5 .8 to 36680.6 eggs per $\mathrm{cm}$. although, fish fecundity of $S$. solea increased with the body weight get heavier (Fig. 11) and represented by the following linear regression: $\mathrm{F}=188892+4683.8 \mathrm{~W}\left(\mathrm{R}^{2}=0.9178\right)$.

On the other hand, the relative fecundity was decreased from about 51000 egg per $1 \mathrm{~g}$ body weight in lighter individuals $(23.9 \mathrm{~g})$ to be about 4560 per $1 \mathrm{~g}$ in heavier individual $(225.3 \mathrm{~g})$.

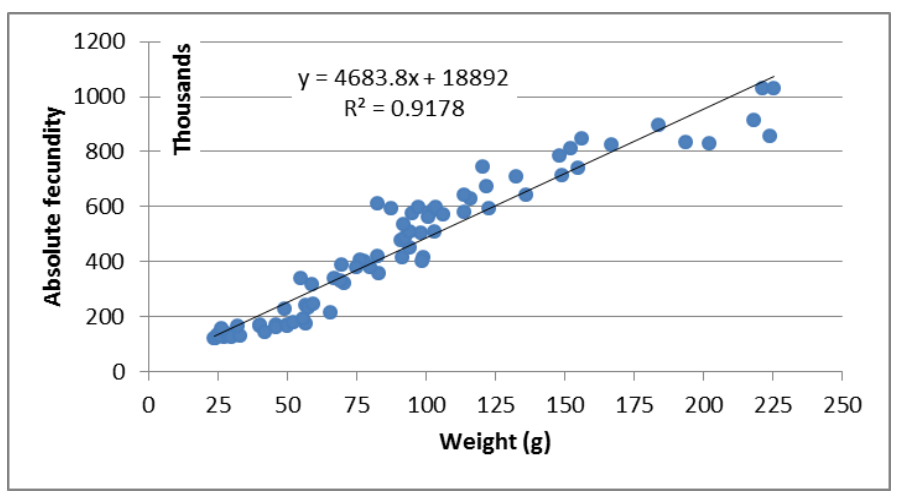

Fig. 11: Relationship between body weight (g) and absolute fecundity of S. solea from Bardawil Lagoon during 2016-207. 


\section{DISCUSSION}

In the present work, the length - weight relationship exhibits allometric growth and was described by the power equation: $\mathrm{W}=0.0055 \mathrm{~L}^{3.171}, \mathrm{~W}=0.0047 \mathrm{~L}^{3.2334}$ and $\mathrm{W}=0.0048 \mathrm{~L}^{3.2215}$ for males, females and combined sexes respectively. Mehanna et al., (2015) mentioned that the estimated length - weight equations of Solea solea from Egyptian Mediterranean coast off Alexandria were, $\mathrm{W}=0.0201 \mathrm{~L}^{2.7032}, \mathrm{~W}=0.0125 \mathrm{~L}^{2.8883}$ and $\mathrm{W}=0.0131 \mathrm{~L}^{2.8615}$ for males, females and combined sexes respectively. Desouky (2016) pointed out that the lengthweight relationship of Solea solea in Lake Qarun is described by the equation: $\mathrm{W}=0.01 \mathrm{~L}^{2.932}$. Başaran et al. (2008) found that the length- weight relationship of S. solea in Izmir Bay, Turkey, was represented by a power equation $\left(\mathrm{W}=0.0025 \mathrm{~L}^{3.3631}\right)$. These differences maybe due to food availability, size range and/or physicochemical parameters.

The overall sex ratio between males and females of Solea solea in Bardawil Lagoon was 1: 1.99. Our results agree with Ahmed et al., (2010), since they found that females' number was greater than that of male of S. aegyptiaca in Port Said, Egypt, Mediterranean Sea. Also in the present study, the sex ratios varied monthly with different length groups and there were deviations from the expected ratio 1: 1. Türkmen (2003) recorded that the overall sex ratio of males and females of S. solea from Turkey were 1.03: 1. Mehanna (2014) reported that the sex ratio of common soles collected from Bardawil Lagoon was 1: 2.11(males: females). Khalifa et al., (2018) mentioned that sex ratio of S. aegyptiaca was in favour of males in smaller sizes and females in larger sizes in Tunian waters. These differences may be attributed to the different ecological conditions especially temperature or to the encounter to fishing gears (Gabr, 2015).

In the present study, the highest value of female GSI recorded in December (8.72). This means that $S$. solea in Bardawil Lagoon is a winter spawner. The reproductive season of $S$. aegyptiaca in southern Tunisian waters (Central Mediterranean) extended from October to February, with GSI peaking in November and December for males and females respectively (Khalifa et al., 2018).

The recorded lengths at first maturity $\left(\mathrm{L}_{50}\right)$ was determined as 19.8 and $20.1 \mathrm{~cm}$ for males and females respectively. This nearly agrees with Mehanna (2014), since it was found that $\mathrm{L}_{50}$ of $S$. solea was 18.7 and $19.6 \mathrm{~cm}$ TL for males and females respectively. Ahmed et al. (2010) mentioned that female S. aegyptiaca from Egyptian water of Mediterranean attains its maturity at $15.0 \mathrm{~cm}$ of total length. This may be attributed to the difference in mesh size used. The estimated average length at first maturity in Tunisian waters was 22.31 and 23.19 $\mathrm{cm}$ for males and females of S. aegyptiaca respectively (Khalifa et al., 2018).

The number of eggs gradually increased by increasing fish length or weight, since fish of $14 \mathrm{~cm}$ (23.8 g.) carry about 121369 eggs, reaching maximum of about 1028111 eggs for a fish length $28.5 \mathrm{~cm},(225.3 \mathrm{~g}$.). The relative fecundity gradually increased from 8093 to 36681 eggs per $\mathrm{cm}$. Khalifa et al., ( 2018) reported that total fecundity of mature females of S. aegyptiaca ranged from 14160 to 62700 eggs per fish, showing a significant increase with size, with an average of 33020 eggs per fish.

\section{CONCLUSION}

The length - weight relationship of $S$. solea in Bardawil Lagoon exhibits allometric growth. Females predominated during all months, since it constitutes more than $60 \%$ of the collected sample during the period of study. S. solea in Bardawil Lagoon is a winter spawner, and the female attains its maturity at $20.1 \mathrm{~cm}$ of total length. Regulations should also be directed to equal length at first capture by the length at first mature and not less than $20.5 \mathrm{~cm}$ 
to give the females the chance to spawn even once to preserve or conserve the stock of the fish in Bardwill Lagoon.

\section{REFERENCES}

Ahmed, A.; Sharaf, M. M. and Laban, H. A. (2010). Reproduction of the Egyptian sole, solea aegyptiaca (actinopterygii: Pleuronectiformes: soleidae), from Port Said, Egypt, Mediterranean Sea. Acta ichthyologica et piscatoria , 40 (2): 161-166.

Albertine-Berhaut, J. (1973) . Biologie de stades juveniles de téleostéens mugilidae Mugil auratus Risso 1810, Mugil capito Cuvier 1829, et Mugil salines Risso 1810: I. Régime alimentaire. Aquaculture 2: 251-266. DOI: 10.1016/0044-8486(73)90158-0.

Başaran, F.; Aydoğan, B.; Paruğ, S. S.; Metin, G.; Ulaş, A.; Sayg, H.; Sezen, B. and Hoşsucu, B. (2008). Survival Rates of Common Sole (Solea solea L.) Captured by Gill Nets and Trawl from İzmir Bay; Adaptation to Culture Conditions and Feeding Behavior. Journal of Fisheries \& Aquatic Sciences, Vol. 25(1): 57-61.

Desouky, M. G. (2016). Population dynamics of the Egyptian sole Solea aegyptiaca Chabanaud, 1927 (Osteichthyes: Soleidae), in Qarun Lake, Egypt. Int. J. Fish. \& Aqua. Stu. , 4(5): 421-425.

Gabr, H. R.; Ahmed A. I. and Haraz M. (2003). Aquaculture potential of the flatfish Solea vulgaris in Egypt. Journal Of Egyptian Academic Socity for Environmental Development, Aquaculture B 4 (2): 157-168.

Gabr, H.M. (2015). Capture production and stock assessment of Solea aegyptiaca Chabanaud, 1927 (Soleidae: Pleuronectiformes) in Bardawil Lagoon, Egypt. Egyp. J .Aqu. Res. 41,101- 110.

GAFRAD, General Authority for Fish Resources Development (2018)., Annual reports of fish statistics, Cairo, Egypt.

García-López, Á.; Fernández-Pasquier, V.; Couto, E.; Canario, A. V. M.; Sarasquete, C. and Martínez-Rodríguez, G. (2006). Testicular development and plasma sex steroid levels in cultured male Senegalese sole Solea senegalensis Kaup. General and Comparative Endocrinology 147 (3): 343-351. DOI: 10.1016 /j.ygcen. 2006. 02.003.

Hile, R. (1936). Age and growth of the Cisco, Leu cichthys artedi (Le Sueur) in the lakes of the Northeastern high-lands, Wisconsin. Bull. Bur. Fish. U. S., 48(19): 211-317.

Khalifa, F.; Taieb, A. H.; Hajji, F. and Ayadi, H. (2018). Reproductive biology of the Egyptian sole, Solea aegyptiaca (Actinopterygii: Pleuronectiformes: Soleidae), in southern Tunisian waters (Central Mediterranean). Journal of the Marine Biological Association of the United Kingdom, 1- 7.

Mehanna, S. F. (2007). Stock assessment and management of the Egyptian sole Solea aegyptiaca Chabanaud, 1927 (Osteichthyes: Soleidae), in the southeastern Mediterranean, Egypt. Turkish Journal of Zoology 31: 379-388.

Mehanna, S. F. (2014). Reproductive dynamics of the common sole Solea solea (Linnaeus, 1758) from Bardawil Lagoon, North Sinai, Egypt. Tropentag 2014: Conference on International Research on Food Security, Natural Resource Management and Rural Development. Organized by the Czech University of Life Sciences Prague.

Mehanna, S. F. ; Abu El-Regal, M. and Aid, N. M. (2015). Age and Growth of the Common Sole Solea solea from Egyptian Mediterranean coast off Alexandria. Egypt. J. Aquat. Biol. \& Fish., Vol. 19, No. 2: 59-64

Morgan, M. J. (2008). Integrating Reproductive Biology into Scientific Advice for Fisheries Management. J. Northw. Atl. Fish. Sci., Vol. 41: 37-51.

Narimatsu, Y.; Kitagawa, D.; Hattori, T. and Onodera, H. ( 2005). Reproductive biology of female Rikuzen sole (Dexistes rikuzenius). Fishery Bulletin 103 (4): 635-647. 
Nikolsky, G. V. (1963): The Ecology of fishes. Academic Press, London and New York. $352 \mathrm{p}$.

Noor-ElDeen, A. I. E.; Eissa, I. A. M.; Mehanna, S. F.; El-Sayed, A. B. and Zaki, M. S. (2016). Ecology of Lake Bardawil: A Preliminary Review. International Journal of Environmental Sciences. Vol. 5 No. 1. 2016. Pp. 28-31.

Rajaguru, A. (1992). Biology of co-occurring tonguefishes, Cynoglossus arel and C. lida (Pleuronectiformes:Cynoglossidae), from Indian waters. Fishery Bulletin 90 (2): 328367.

Ricker, W. E. (1975). Computation and interpretation of biological statistics of fish populations. Bull. Fish. Res. Board Canada, 191:382 p.

Salman, S. (2014). Fisheries characteristics and population dynamics of commercial species of family Soleidae in Bardawil Lagoon, North Sinai, Egypt. MSc. Thesis, Suez Canal University.

Sendecor, G. W. (1956): Statistical methods. Iowa State College Press, 5th ed. 534p.

Türkmen, M. ( 2003). Investigation of some population parameters of common sole, Solea solea (L., 1758) from -skenderun Bay. Turkish Journal of Veterinary and Animal Sciences 27: 317-323.

Vallisneri, M.; Tinti, F.; Tommasini, S. and Piccinetti, C. ( 2001). Reproductive cycle of the common sole Solea vulgaris, Quensel, 1806 in the northern Adriatic Sea. Acta Adriatica 42 (2): 59-63.

Yeldan, H. and Avşar, D. ( 2000). A preliminary study on the reproduction of rabbit fish, Siganus rivulatus (Forsskål, 1775), in the northeastern Mediterranean. Turk. J. Zool. 24: 173-182.

Zaki, M. I. and Hamza, A. K. (1986). Reproductive biology and induced spawning of Solea solea (L.) in Egypt. Bulletin of the National Institute of Oceanography and Fisheries (Egypt) 12: 115-125.

\section{ARABIC SUMMARY}

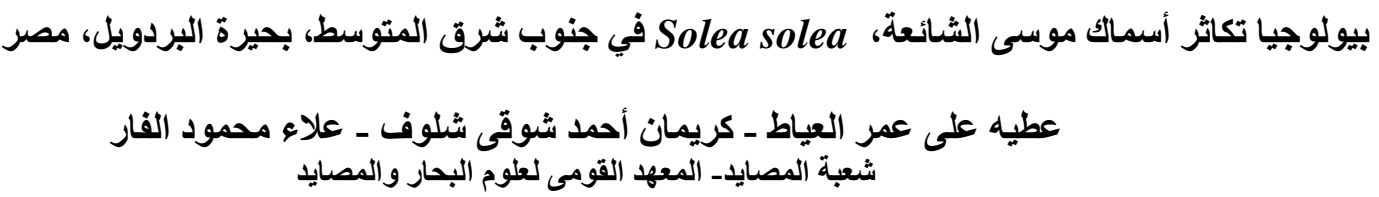

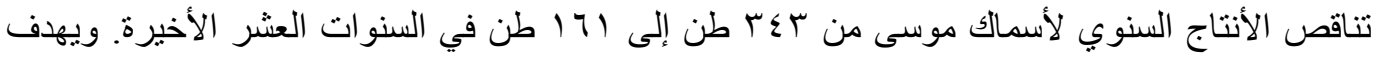

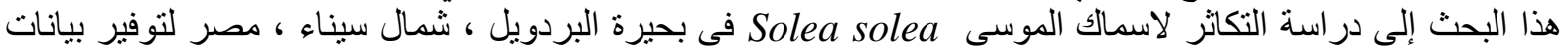
بيولوجية لإدارة مصايد هذا النوع في البحيرة. تم تجميع عينات شهريا من مناطق الانزال المختلفة في بحيرة البردويل

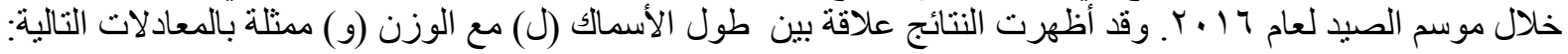

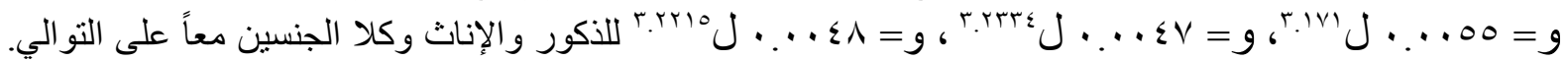

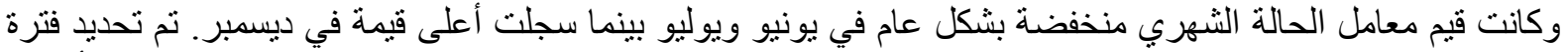

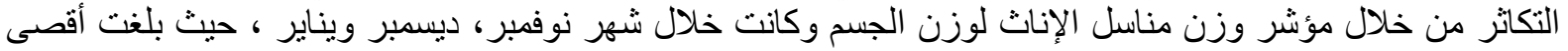

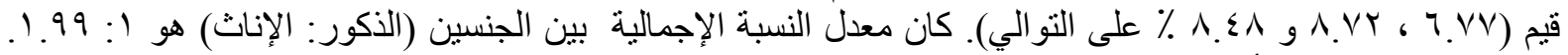

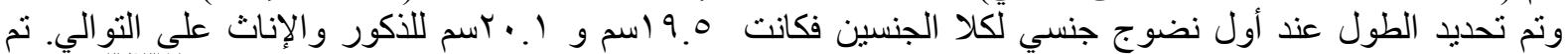

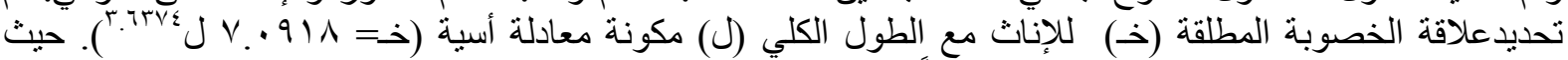

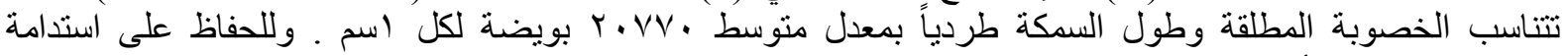

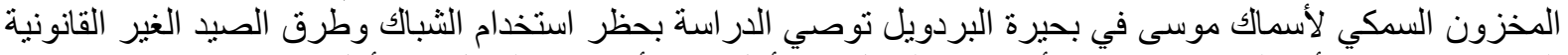

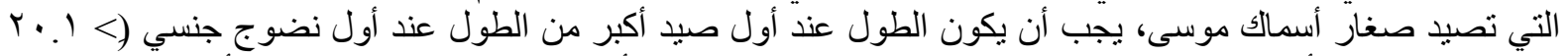

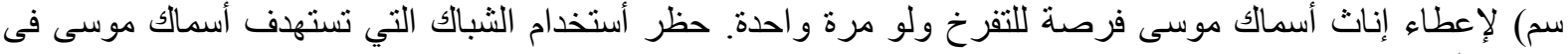
فترات التكاثر (نوفمبر - ديسمبر - بناءير). 